\title{
FAKTOR-FAKTOR YANG MENENTUKAN HASIL PRODUKSI PADI SAWAH DI DESA MAKARTI KECAMATAN KAO BARAT KABUPATEN HALMAHERA UTARA
}

\author{
Dedison Saketa \\ Oktavianus Porajouw \\ Elsje Pauline Manginsela
}

\begin{abstract}
This study aims to describe the determinants of land area, capital and labor to the production of lowland rice. This research was conducted in Makarti Village, West Kao District, North Halmahera Regency. This research lasted for three months, namely from March to May 2017. Sampling in this study used proportional area random sampling. The data used in this study were primary data and secondary data. The results of the study indicated that the area of land determines the yield of production because by adding land area the yield will tend to increase. Capital determines production results because by adding capital it can increase production. Labor also determines the yield of rice. These three factors are closely related and mutually supportive in increasing the yield of rice cultivation. This study concludes that the determinants of land area, capital, and labor tend to increase the yield of rice production. *epm*
\end{abstract}

Keywords: determinant, capital, labor, land size, yield production, North Halmahera Regency

\begin{abstract}
ABSTRAK
Penelitian ini bertujuan untuk mendeskripsikan faktor-faktor penentu yaitu luas lahan, modal dan tenaga kerja terhadap produksi padi sawah. Penelitian ini telah di lakukan di Desa Makarti Kecamatan Kao Barat Kabupaten Halmahera Utara. Penelitian ini berlangsung selama tiga bulan yaitu dari bulan Maret hingga bulan Mei 2017. Pengambilan sampel dalam penelitian ini menggunakan teknik pengambilan sampel berdasarkan wilayah dimana masing-masing bagian terambil sampelnya secara acak (proporsional area random sampling). Data yang digunakan dalam penelitian ini adalah data primer dan data sekunder. Hasil penelitian menunjukkan bahwa luas lahan menentukan hasil produksi karena dengan menambahkan luas lahan maka hasil produksi akan cenderung meningkat. Modal menentukan hasil produksi karena dengan menambahkan modal maka dapat meningkatkan hasil produksi. Tenaga Kerja juga menentukan hasil produksi padi. ketiga faktor tersebut sangat berkaitan erat dan saling mendukung dalam meningkatkan hasil produksi budidaya padi sawah. Penelitian ini menyimpulkan bahwa faktor penentu berupa luas lahan, modal, dan tenaga kerja cenderung dapat meningkatkan hasil produksi padi sawah. *epm*
\end{abstract}

Kata kunci: faktor penentu, modal, tenaga kerja, luas lahan, hasil produksi,

Kabupaten Halmahera Utara.

Agrisosioekonomi: 


\section{PENDAHULUAN}

\section{Latar Belakang}

Indonesia merupakan negara agraris dimana pertanian memegang peranan penting pada perekonomian nasional. Untuk mengimbangi semakin pesatnya laju pertumbuhan penduduk Indonesia, maka usaha pertanian yang maju perlu digalakkan diseluruh kawasan pertanian Indonesia. Dalam upaya membangun pertanian Indonesia agar kualitas dan kuantitas produk pertanian dapat ditingkatkan maka diperlukan peran pemerintah dalam hal kebijakan pertanian guna pencapaian pemerataan swasembada pangan. Pembangunan sektor pertanian merupakan sektor yang diutamakan terkait dengan kesejahteraan petani.

Masing-masing faktor mempunyai fungsi yang berbeda dan saling terkait satu sama lain. Kalau salah satu faktor tidak tersedia maka proses produksi atau usaha tani tidak akan berjalan, terutama ketiga faktor seperti tanah, modal dan tenaga kerja (Daniel, 2004).

Faktor produksi tanah terdiri dari beberapa faktor alam lainnya seperti air, udara, temperatur, sinar matahari, dan lainnya. Keberadaan faktor produksi tanah, tidak hanya dilihat dari segi luas sempitnya saja, tetapi juga dari segi yang lain, seperti jenis tanah, macam penggunaan lahan (tanah sawah, tegalan, dan sebagainya), topografi (tanah dataran tinggi, rendah, dan dataran pantai), pemilikan tanah, dan nilai tanah (Whittow, 1994).

Selain faktor produksi tanah, pertanian juga dipengaruhi oleh faktor produksi modal. Makin tinggi modal per unit usaha digunakan maka usaha tersebut dinamakan makin padat modal atau makin intensif. Apakah makin intensif suatu usaha maka makin tinggi atau tidak keuntungannya itu masih dipengaruhi oleh faktor harga output dan harga input.

Sama seperti tanah dan modal, tenaga kerja juga mempunyai peran yang penting dalam produksi pertanian. Dalam ilmu ekonomi yang dimaksud tenaga kerja adalah suatu alat kekuatan fisik dan otak manusia, yang tidak dapat dipisahkan dari manusia dan ditujukan pada usaha produksi. Menurut sebagian pakar ekonomi pertanian, tenaga kerja (man power) adalah penduduk dalam usia kerja, yaitu yang berumur 10-64 tahun, merupakan penduduk potensial yang dapat bekerja untuk memproduksi barang atau jasa Sebagai salah satu kabupaten di Indonesia, Kabupaten Halmahera Utara masih mempunyai wilayah (Soekartawi, 1984).

Pengembangan pertanian sebagai sumber daya yang dapat dimanfaatkan untuk kegiatan meningkatkan produksi pertanian dan kesejahteraan masyarakat. Pemanfaatan potensi ini dapat dilaksanakan dengan optimal melalui keterlibatan masyarakat terutama para petani. Dalam undang-undang No. 24/1992 tentang penataan ruang menyebutkan bahwa kawasan desa adalah kawasan fungsional dengan ini kegiatan utama desa adalah sektor pertanian. Oleh sebab itu, strategi pembangunan harus mampu menjawab tantangan pembangunan perdesaan. Pengembangan usaha pertanian di Kabupaten Halmahera Utara dilaksanakan di setiap desa. Salah satunya adalah pemanfaatan lahan pertanian di Desa Makarti Kecamatan Kao Barat Kabupaten Halmahera Utara yang dikembangkan demi kesejahteraan petani dan untuk mencukupi kebutuhan masyarakat agar tetap terus berjalan sesuai dengan tujuan pembangunan. Salah satu komoditas pertanian di Indonesia yang merupakan komoditas potensial adalah komoditas tanaman padi. Tanaman padi merupakan salah satu tanaman yang memegang peranan penting bagi perekonomian negara yaitu sebagai bahan untuk mencukupi kebutuhan pokok masyarakat maupun sebagai mata pencaharian serta sebagai sumber pendapatan petani dalam memenuhi kebutuhan hidupnya.

Komoditas tanaman padi ini pula yang kini menjadi tumpuan hidup masyarakat petani yang ada di Desa Makarti Kecamatan Kao Barat Kabupaten Halmahera Utara. Luas areal pertanian di Desa Makarti yaitu sebesar 350 hektare, sedangkan luas pemukimannya 
adalah 20 hektare. Ini menunjukkan bahwa sebagian besar wilayah di Desa Makarti merupakan areal pertanian. Namun luas areal ini tidak sebanding dengan jumlah panen padi yang dihasilkan. Dahulu saat panen berhasil rata-rata padi yang dihasilkan yaitu sebesar 67 ton basah/ha ( $>0,8$ ton/kotak), tetapi saat ini hasil itu sangat sulit dicapai.

Petani padi sawah yang ada di Desa Makarti Kecamatan Kao Barat Kabupaten Halamahera Utara adalah masyarakat transmigrasi atau masyarakat pindahan dari pulau Jawa. Setiap lahan yang di miliki oleh petani padi sawah adalah pemberian dari pemerintah yang sudah menjadi hak milik setiap petani. Tetapi yang menjai permasalahan saat ini bagi usahatani padi sawah yang ada di Desa Makarti Kecamatan Kao Barat Kabupaten Halmahera Utara adalah Bahwa Luas lahan yang di miliki petani tidak sesuai dengan hasil yang di terima, sehingga dengan demikian dapat di simpulkan bahwa para petani mengalami kerugian.

\section{Rumusan Masalah}

Berdasarkan latar belakang yang telah di uraikan, maka rumusan masalah dalam penelitian ini adalah apakah besar luas lahan, modal dan tenaga kerja menentukan produksi padi di Desa Makarti Kecamatan Kao Barat Kabupaten Halmahera Utara?

\section{Tujuan Penelitian}

Tujuan penelitian ini adalah untuk mendeskripsikan faktor-faktor penentu yaitu luas lahan, modal dan tenaga kerja terhadap produksi padi sawah di Desa Makarti Kecamatan Kao Barat Kabupaten Halmahera Utara.

\section{Manfaat Penelitian}

Manfaat penelitian adalah:

1. Mampu memberikan kontribusi untuk memperkuat penelitian sebelumnya, serta menambah informasi dan sumbangan serta bahan kajian bagi penelitian selanjutnya khususnya mengenai besarnya penentu luas lahan, modal, dan tenaga kerja terhadap produksi padi.

2. Menambah ilmu pengetahuan khususnya di bidang ekonomi pembangunan.

\section{METODE PENELITIAN}

\section{Tempat dan Waktu Penelitian}

Penelitian ini telah di lakukan di Desa Makarti Kecamatan Kao Barat Kabupaten Halmahera Utara. Penelitian ini berlangsung selama tiga bulan yaitu dari bulan Maret hingga bulan Mei 2017.

\section{Populasi}

\section{Populasi dan Sampel}

Populasi dalam penelitian ini adalah seluruh petani yang melakukan usahatani padi sawah di Desa Makarti Kecamatan Kao Barat Kabupaten Halmahera Utara.

\section{Sampel}

Pengambilan sampel dalam penelitian ini menggunakan teknik Proporsional Area Random Sampling, yaitu pengambilan sampel berdasarkan wilyah dimana masing-masing bagian terambil sampelnya secara acak. Dengan demikian peneliti memberikan hak yang sama kepada objek untuk memperoleh pertanyaan dan dipilih menjadi sampel di masing-masing area atau wilayah bagian sampel dalam penelitian ini yang mewakili populasi terdiri dari petani padi dari dua dusun yaitu dusun 1 (satu), dan dusun 2 (dua) Penentuan sampel ini dihitung dengan menggunakan rumus Slovin dalam Husein (1998:78-79) berikut ini:

Keterangan:

$\mathrm{N}=$ ukuran populasi

$\mathrm{n}=$ ukuran sampel

$\mathrm{e}^{2}=$ persen kelonggaran ketidak telitian karena kesalahan pengambilan Sampel yang ditolelir, dalam penelitian ini digunakan 10 persen.

Berdasarkan rumus di atas, maka perhitungan nilai sampel sebagai berikut :

$$
\mathrm{n}=\frac{115}{1+115.0,1}
$$




$$
\begin{aligned}
& n=\frac{115}{1+3,23} \\
& \mathrm{n}=\frac{115}{4,23} \\
& \mathrm{n}=28
\end{aligned}
$$

Perhitungan di atas diperoleh nilai sampel yang digunakan dalam penelitian ini, yaitu sebanyak 28 petani padi dianggap sudah mewakili dari keseluruhan petani yaitu sebanyak 115 orang petani. Adapun proporsi sebaran sampelnya yang terdapat pada dua dusun di Desa Makarti yaitu Dusun 1 (satu) dan Dusun 2 (dua) dapat dilihat pada Tabel 1.

Tabel 1. Sebaran Sampel Petani Padi di Desa Makarti Kecamatan Kao Barat Kabupaten Halmahera Utara

\begin{tabular}{cccc}
\hline No & Dusun & Populasi & Sampel \\
\hline 1 & Dusun 1 & 56 & $\frac{56}{115} \times 28=14$ \\
2 & Dusun 2 & 59 & $\frac{59}{115} \times 28=14$ \\
\hline & Jumlah & 115 & 28 \\
\hline
\end{tabular}

\section{Konsep Pengukuran Variabel}

a. Luas Lahan (LL)

Dalam penelitian ini peneliti menggunakan lahan dengan memandang dari mana diperolehnya atau status tanah tersebut. Dengan indikator, luas lahan yang digunakan per kegiatan untuk menanam tanaman padi dalam satuan hektare (ha).

b. Modal (M)

Modal dalam penelitian ini menggunakan indikator:

1) Biaya sarana produksi besaran nominal berupa uang (Rupiah) yang dipergunakan untuk pembelian bahan produksi dalam satu kali masa tanam.

2) Biaya tenaga kerja besaran nominal berupa uang (Rupiah) yang di gunakan untuk pembiayaan tenaga kerja dalam satu kali masa tanam.

\section{c. Tenaga Kerja (TK)}

Tenaga Kerja dalam penelitian ini yaitu menggunakan jumlah tenaga kerja yang digunakan per kegiatan dalam satu kali masa tanam didasarkan pada satuan hari orang kerja dihitung dengan anggapan satu hari kerja dengan satuan ukur (jumlah orang).

\section{d. Produksi}

Produksi dalam penelitian ini adalah hasil produksi padi dengan indikator besarnnya jumlah produksi padi yang diproduksi atau dihasilkan oleh petani dalam satuan karung di Desa Makarti Kecamatan Kao Barat Kabupaten Halmahera Utara.

\section{Jenis dan Sumber Data}

Data yang digunakan oleh peneliti adalah data primer dan data sekunder. Data primer diperoleh dari hasil wawancara langsung dengan para petani padi dengan menggunakan daftar pertanyaan (kuesioner) yang telah disusun sebelumnya sesuai dengan apa yang akan menjadi penelitiannya.

Sedangkan data sekunder adalah data yang diperoleh dari catatan atau sumber lain yang telah ada sebelumnya dan diolah kemudian disajikan dalam bentuk teks, karya tulis, laporan penelitian, buku dan lain sebagainya. Data sekunder yang dibutuhkan diperoleh dari Statistik desa dan catatan-catatan Desa Makarti.

\section{Metode Pengumpulan Data}

Metode pengumpulan data merupakan suatu cara untuk memperoleh bahan-bahan keterangan atau kenyataan yang benar-benar mengungkapkan data-data yang diperlukan dalam suatu penelitian baik untuk data yang pokok maupun data penunjang. Adapun metode yang digunakan dalam penilitian ini adalah sebagai berikut:

\section{Kuesioner}

Dalam penelitian ini, kuesioner digunakan sebagai metode utama mengumpulkan data dengan cara isi setiap pertanyataan yang berkaitan dengan luas lahan, modal, dan tenaga kerja terhadap produksi petani padi di Desa Makarti Kecamatan Kao Barat Kabupaten Halmahera Utara lalu di berikan kepada setiap petani padi Sawah yang menjadi responden.

\section{Wawancara}

Metode ini dilakukan pada saat melakukan pengumpulan data dengan cara bertanya kepada petani tentang luas lahan, 
Modal dan Tenaga Kerja terhadap hasil produksi. Serta membantu menjelaskan kepada responden yang tidak bisa menjawab kosioner yang di karenakan buta huruf atau ataupun keterbatasan dalam memahami setiap pertanyaan.

\section{Dokumentasi}

Metode dokumentasi ini digunakan untuk mengumpulkan data fisik dan kondisi wilayah di Desa Makarti Kecamatan Kao Barat Kabupaten Halmahera Utara, seperti luas wilayah, batas wilayah, jumlah penduduk, dan mata pencaharian penduduk.

\section{Metode Analisis Data}

Metode analisis merupakan suatu usaha untuk menentukan jawaban atas pertanyaan tentang rumusan dan hal-hal yang diperoleh dalam suatu penelitian. Data yang sudah masuk dan sudah terkumpul dianalisis untuk menjawab tujuan dari penelitian. Teknik analisis data disesuaikan dengan tujuan penelitian. Adapun teknik analisis data yang digunakan dalam penelitian ini adalah:

\section{Metode Analisis Deskriptif}

Metode ini dapat diartikan sebagai proses pemecahan masalah yang diselidiki dengan melukiskan keadaan subyek dan obyek penelitian pada saat sekarang berdasarkan faktafakta yang tampak atau bagaimana adanya. Penelitian deskriptif berkaitan dengan pengumpulan data untuk memberi gambaran atau penegasan suatu konsep, menjawab pertanyaan-pertanyaan sehubungan dengan status subyek penelitian (Wirartha, 2006).

\section{HASIL DAN PEMBAHASAN}

\section{Gambaran Umum Daerah Penlitian}

Wilayah penelitian ini di laksanakan di Desa Makarti Kecamatan Kao Barat Kabupaten Halmahera utara. Desa Makarti terletak sebelah Utara dari ibukota Kecamatan Kao Barat. Jarak antara ibukota kecamatan dan pusat pemerintahan Desa Makarti yaitu $3 \mathrm{~km}$. Desa Makarti terdiri dari 2 Dusun yaitu dusun 1 (satu) dan dusun 2 (dua). berikut:

$$
\text { Batas-batas Desa Makarti sebagai }
$$

1. Sebelah Utara : Desa Kai

2. Sebelah Selatan : Desa Torawat

3. Sebelah Barat : Desa Tolabit

4. Sebelah Timur : Desa Soahukum

Desa Makarti memiliki luas wilayah sebesar 575 ha yang penggunaannya yaitu sebagai berikut:

Tabel 2. Presentase Luas Lahan, dan MasingMasing Penggunaan Lahan

\begin{tabular}{llcc}
\hline No. & $\begin{array}{c}\text { Pengunaan } \\
\text { Lahan }\end{array}$ & $\begin{array}{c}\text { Luas Lahan } \\
(\text { ha })\end{array}$ & $\begin{array}{c}\text { Persentase } \\
(\%)\end{array}$ \\
\hline 1. & Tanah Sewa & 350 & 61 \\
2. & Pemukiman & 30 & 5 \\
3. & Jalan & 6 & 1 \\
4. & Kuburan & 12,5 & 2 \\
5. & Lain-lain & 176,5 & 31 \\
\hline & Total & 575 & 100 \\
\hline
\end{tabular}

Dari 575 ha lokasi yang di miliki oleh Desa Makarti menurut penggunaan yang paling besar adalah lahan sawah, selanjutnya penggunaan kedua yang paling besar adalah untuk pemukiman. Selain itu sisanya yang lain digunakan untuk jalan aspal dan tempat pemakaman. Hal ini juga dapat di lihat pada Gambar 1.

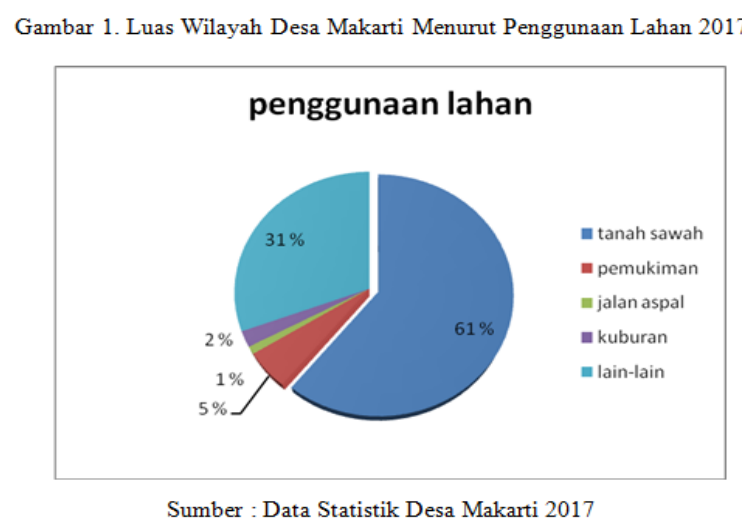

Jumlah penduduk di Desa Makarti yaitu sebanyak 498 dengan rincian laki-laki berjumlah 262 dan perempuan 236 jiwa. Sebagian besar masyarakat di Desa Makarti bermata pencaharian sebagai petani yaitu sebanyak 115 orang, dan selanjutnya terbesar kedua yaitu Peternak 25 orang dan terbesar yang ketiga adalah bermata pencaharian sebagai Tukang 15 orang. Dan untuk lebih jelas lagi dapat di lihat pada Gambar 2. 
Gambar 2. Mata Pencaharian Penduduk Desa Makarti Kecamatan Kao Barat Kabupaten Halmahera Utara Tahun 2017

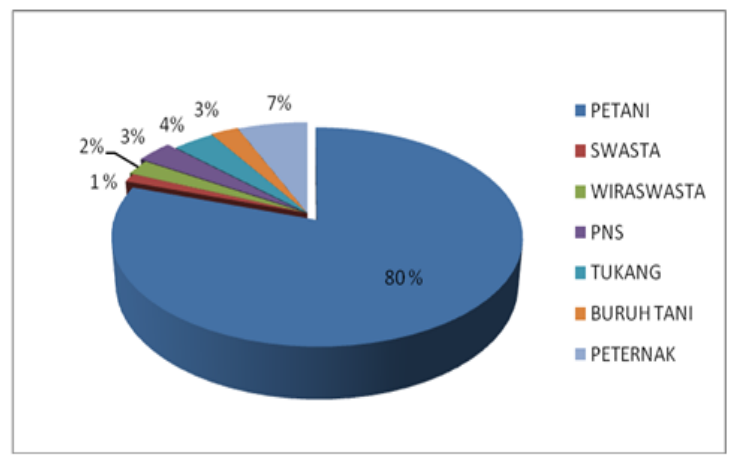

\section{Analisis Deskripsi Penelitian}

Sesuai dengan tujuan penelitian yaitu untuk mengetahui deskripsi tentang luas lahan, modal, tenaga kerja dan produksi padi petani serta untuk mengetahui ada tidaknya pengaruh luas lahan, modal dan tenaga kerja terhadap hasil produksi padi petani di Desa Makarti Kecamatan Kao Barat Kabupaten Halmahera Utara. Maka data yang di peroleh dari pengisian angket di analisis melalui analisis deskriptif. Analisis deskriptif bertujuan untuk memberikan penjelasan dari masing-masing variable.

Deskripsi dari masing-masing variabel yaitu luas lahan, modal, tenaga kerja dan produksi padi petani di Desa Makarti Kecamatan Kao Barat Kabupaten Halmahera Utara dapat di ketahui dari analisis deskriptif. Analisis dari masing-masing faktor yaitu sebagai berikut.

\section{Luas Lahan}

Gambaran tentang luas lahan pertanian Petani di Desa Makarti Kecamatan Kao Barat Kabupaten Halmahera Utara, berdasarkan angket masing-masing responden diperoleh hasil dan di tuangkan pada Tabel 3.

Tabel 3. Variabel Luas Lahan Pada Usahatani Padi di Desa Makarti Kecamatan Kao Barat Kabupaten Halmahera Utara 2017

\begin{tabular}{cccc}
\hline No & Luas Lahan $(\mathrm{Ha})$ & Frekuensi & Persentase $(\%)$ \\
\hline 1 & 0,75 & 15 & 53 \\
2 & 1 & 8 & 29 \\
3 & 1,5 & 5 & 18 \\
\hline & Total & 28 & 100
\end{tabular}

Sumber : Data Primer Diolah 2017
Berdasarkan Tabel 3 menunjukan bahwa 15 petani (53\%) memiliki luas lahan sebesar 0,75 atau hampir 1 ha, dan ada 8 petani (29\%) yang memiliki luas lahan sebesar 1 ha (100 m X $100 \mathrm{~m})$. selanjutnya ada $5(18 \%)$ petani yang menyatakan luas lahan 1,5 Ha.

Berdasarkan hasil penelitian bahwa terlihat luas lahan pertanian yang di miliki oleh petani di Desa Makarti yang paling banyak adalah $0,75 \mathrm{Ha}$ atau hampir satu hektar. Sedangkan yang memiliki 1,5 ha (satu koma lima hektar) itu sangat sedikit. Menurut petani hal tersebut di karenakan para petani hanya sebagai penduduk pindahan atau dengan kata lain transmigrasi sehingga lahan yang di dapat hanya di berikan oleh Pemerintah Kabupaten Halmahera Utara sebagai hak milik (tanah sendiri), dan setiap petani yang memiliki lahan lebih dari satu hektar (1 ha) adalah petani yang mempunyai usaha sampingan yaitu warung sehingga dengan modal tersebut petani bisa membeli sebidang lahan dari penduduk di sekitar kampung atau trans tersebut. Dan untuk lebih jelas dapat di lihat pada Gambar 3.

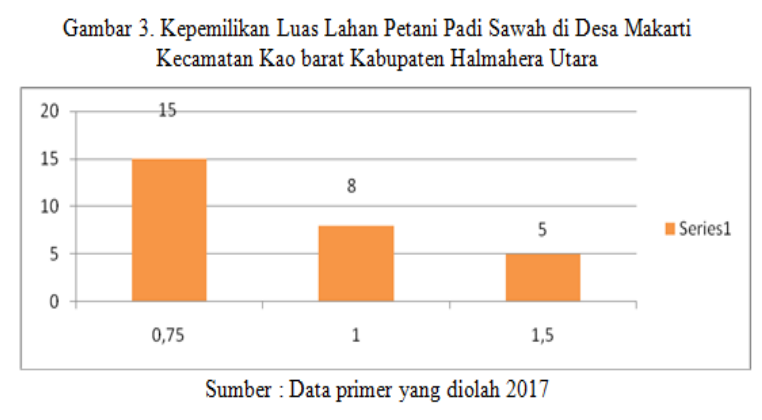

Modal

Dari hasil penelitian untuk Modal dapat di sajikan pada Tabel 4.

Tabel 4. Modal pada Usaha Tani Padi Sawah di Desa Makarti Kecamatan Kao Barat Kabupaten Halmahera Utara

\begin{tabular}{ccc}
\hline Modal $(\mathrm{Rp})$ & Frekuensi & Persentase $(\%)$ \\
\hline $3,145,000-3,760,000$ & 14 & 50 \\
$4,180,000-4,997,000$ & 7 & 25 \\
$5,080,000-6,935,000$ & 3 & 11 \\
$7,110,000-8,860,000$ & 4 & 14 \\
\hline Total & 28 & 100 \\
\hline
\end{tabular}

Sumber : Data Primer Diolah 2017 
Berdasarkan hasil penelitian yang di peroleh, maka modal petani di Desa Makarti Kecamatan Kao Barat Kabupaten Halmahera Utara. Yang berada antara Rp.3,145,000 Rp.3,760,000 adalah sebanyak 14 orang (50\%), dan untuk modal petani yang berada pada antara Rp.4,180,000 - Rp.4,997,000 adalah sebanyak 7 orang (25\%) dan selanjutnya untuk Petani yang mempunyai Modal Rp.5,080,000 - Rp.6,935,000 adalah sebanyak $3(11 \%)$ orang dan petani yang mempunyai modal paling banyak di desa makarti yaitu Rp.7,110,000 - Rp.8,860,000 sebanyak 4 orang petani (14\%). Dan untuk lebih jelas lagi dapat di lihat pada Gambar 4.

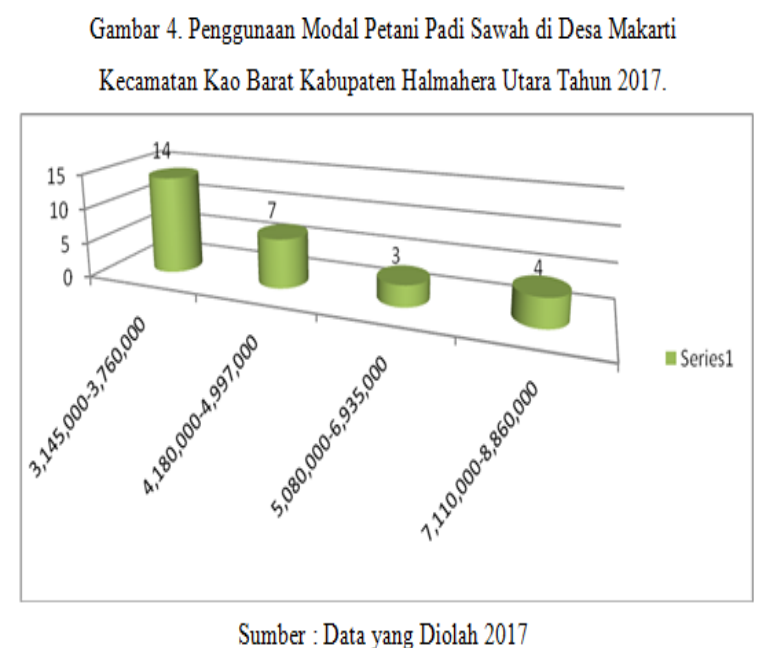

Berdasarkan hasil perhitungan analisis deskriptif untuk Modal menunjukan bahwa, sebagian besar modal di Desa Makarti Kecamatan Kao Barat Kabupaten Halmahera Utara. yaitu Rp.3,145,000 - Rp.3,760,000. sebagian besar modal kepemilikan tanah adalah tanah sendiri atau hak milik sehingga petani tidak mengeluarkan biaya yang besar untuk sewah tanah. Selain itu pengeluaran untuk pembelian bahan-bahan produksi seperti bibit, pupuk, pestisida terbilang sedikit. Jadi biaya yang paling besar yang di keluarkan oleh petani adalah untuk biaya tenaga kerja meskipun sebagian petani menggunakan tenaga sendiri, dari keluarga atau dengan sistim gentian dalam proses produksi.

\section{Tenaga Kerja}

Tabel 6. Tenaga Kerja pada Usaha Tani Padi Sawah di Desa Makarti Kecamatan Kao Barat Kabupaten Halmahera Utara 2017

\begin{tabular}{ccc}
\hline $\begin{array}{c}\text { Tenaga kerja } \\
\text { (HOK) }\end{array}$ & Frekuensi & Persentase (\%) \\
\hline $20-29$ & 14 & 50 \\
$30-40$ & 9 & 32 \\
$52-54$ & 3 & 11 \\
$66-72$ & 2 & 7 \\
\hline Total & 28 & $100 \%$ \\
\hline
\end{tabular}

Sumber: Data Primer Diolah 2017

Berdasarkan hasil penelitian menunjukan bahwa kriteria tenaga kerja yang di gunakan petani agak sedikit berbedah. Faktor tenaga kerja yang di gunakan petani 20-29 orang sebanyak 14 petani $(50 \%)$, dan yang mengunakan tenaga kerja 30-40 orang sebanyak 9 petani (32\%), faktor tenaga kerja yang di gunakan petani 52-54 orang sebanyak 3 petani (11\%), selanjutnya untuk petani yang menggunakan tenaga kerja paling banyak yaitu 66-72 orang sebanyak 2 petani $(7 \%)$. Dan untuk lebih jelas dapat di lihat pada Gambar 5.

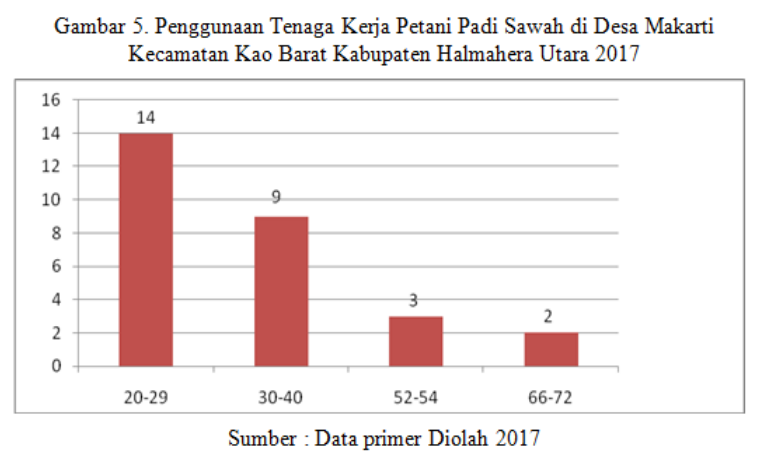

\section{Produksi}

Hasil penelitian yang di peroleh peneliti untuk variabel produksi petani menunjukan data sebagai berikut.

Tabel 7. Kriteria Produksi pada Usaha Tani Padi Sawah di Desa Makarti Kecamatan Kao Barat Kabupaten Halmahera Utara

\begin{tabular}{ccc}
\hline Produksi (Karung) & Frekuensi & Persentase $(\%)$ \\
\hline $53-64$ & 14 & 50 \\
$80-84$ & 9 & 32 \\
$115-130$ & 5 & 18 \\
\hline Total & 28 & 100
\end{tabular}

Sumber : Data Primer Diolah 2017 
Berdasarkan Tabel 7, hasil penelitian deskripsi untuk produksi petani terlihat bahwa ada 14 petani $(50 \%)$ yang hasil produksinya termasuk 53-64 karung. Selanjutnya ada 9 petani $(32 \%)$ yang menyatakan produksinya termasuk 80-84 karung. sedangkan petani yang mempunyai hasil produksi antara 115 130 karung sebanyak 5 petani (18\%).

Hasil penelitian yang menunjukan bahwa sebagian besar hasil produksi padi di Desa Makarti Kecamatan Kao Barat Kabupaten Halmahera Utara yaitu 53-64 karung ini menunjukan secara umum bahwa petani belum memperoleh hasil yang memuaskan dari hasil pertanian yang usahakannya. Karna dahulu hasil petani rata rata 1 ha 300 karung (6,5 ton). Bahkan petani di sana menyebutkan bahwa hasil pertaniannya hanya bisa memenuhi makan keluarganya tanpa untuk menjualnya sehingga sangat sulit untuk memenuhi kebutuhan lainnya. Berdasarkan rendahnya produksi yang di peroleh, jadi dapat di simpulkan bahwa hasil produksi padi di Desa Makarti Kecamatan Kao Barat Kabupaten Halmahera Utara belum bisa di gunakan sebagai mata pencaharian utama yang dapat menopang kehidupan keluarga para petani secara keseluruhan sehingga para petani masih memerlukan usaha lain untuk membiayai kehidupan keluarganya.

\section{Pembahasan}

\section{Deskripsi Luas Lahan, Modal, Tenaga Kerja, dan Hasil Produksi Padi di Desa Makarti Kecamatan Kao Barat Kabupaten Halmahera Utara.}

Berdasarkan hasil penelitian dengan mengunakan alat analisis deskripsi dapat di ketahui sebagai berikut.

\section{Luas Lahan}

Berdasarkan data hasil penelitian ada penemuan penting yaitu:

a) luas lahan menunjukan bahwa sebagian besar luas lahan pertanian yang di miliki petani padi di Desa Makarti Kecamatan
Kao Barat Kabupaten Halmahera Utara tahun 2017 yaitu antara 0,75 $\mathrm{Ha}$ (mendekati satu hektar). Ini terlihat dengan adanya fakta bahwa dari 28 sampel yang di teliti, ada sebanyak 15 petani $(53 \%)$ yang menyatakan memiliki luas lahan sebesar 0,75 ha.

b) Dari seluruh sampel yang ada hanya ada 2 petani yang yang memiliki luas lahan lebih 1,5 ha di Desa Makarti Kecamatan Kao Barat Kabupaten Halmahera Utara. Menurut petani hal tersebut di karenakan para petani hanya sebagai penduduk pindahan atau dengan kata lain transmigrasi sehingga lahan yang di dapat hanya di berikan oleh Pemerintah Kabupaten Halmahera Utara.

\section{Modal}

Terdapat beberapa penemuan berdasarkan penelitian yaitu:

a. Modal terbanyak yang di keluarkan petani padi di Desa Makarti Kecamatan Kao Barat Kabupaten Halmahera Utara. Yaitu Rp.4,685,000. Besar modal tersebut dinyatakan oleh 11 orang petani atau (39\%) dari total 28 petani.

b. Modal tersebut tidak sekali di keluarkan petani tetapi di keluarkan selama proses pengolahan tanah sampai pemanenan dimna setiap tahapan produksi tersebut selalu membutuhkan biaya. Modal tersebut digunakan petani untuk membeli bahan-bahan produksi (bibit, pupuk, obat dan pestisida) dan untuk membayar tenaga kerja.

\section{Tenaga Kerja}

Berdasarkan hasil penelitian ada penemuan yang menunjukan bahwa:

a. Sebanayak $54 \%$ petani atau 15 orang petani di Desa Makarti Kecamatan Kao Barat Kabupaten Halmahera Utara menggunkan tenaga kerja sebanyak 19 orang. Dari jumlah tersebut kebanyak petani di sana juga masih mengerjakan sawahnya dengan tenaga sendiri yang belum masuk di hitung sebagai tenaga kerja. 
b. Perhitungan tenaga kerja yang di pakai dalam penelitian ini yaitu baik yang menggunakan tenaga kerja dari keluarga sendiri maupun adanya sebagian petani yang menggunakan "system gantian" yaitu jika si A hari ini mengerjakan sawahnya di bantu si B maka jika si B kemudian hari mengerjakan sawahnya, akan gantian di bantu oleh si A.

\section{Produksi}

Hasil penelitian deskripsi untuk variaabel produksi terlihat bahwa:

a. Sudah empat tahun terakhir hasil pertanian petani padi di Desa Makarti Kecamatan Kao Barat Kabupaten Halmahera Utara mengalami penurunan. Pada tahun 2017 berdasarkan hasil penelitian menunjukan bahwa hasil pertanian padi petani di Desa Makarti Kecamatan Kao Barat Kabupaten Halmahera Utara yaitu sebesar 78 karung dengan rata-rata harga jual sebesar Rp.75,000/karung.

b. Saat ini kenyataan yang terjadi adalah kebanyakan hasil produksi padi yang di peroleh tidak sebanding dengan semua yang di kelurkan. Sehingga petani di katakana mengalami kerugian dan hasil pertaniannya tidak di jual tetapi untuk di komsumsi sendiri.

Faktor Penentu Luas Lahan, Modal, dan Tenaga Kerja Terhadap Hasil Produksi di Desa Makarti Kecamtan Kao Barata Kabuapaten Halmahera Utara.

Luas Lahan

Tabel 8. Penentu Luas Lahan Terhadap Hasil Produksi di Desa Makarti Kecamtan Kao Barat Kabupaten Halmahera Utara

\begin{tabular}{ccc}
\hline No & Luas Lahan $(\mathrm{Ha})$ & Produksi (karung) \\
\hline 1 & 0,75 & 56 \\
2 & 1 & 82 \\
3 & 1,5 & 120 \\
\hline Rata-rata & 1 & 77 \\
\hline
\end{tabular}

Berdasarkan Tabel 8 di ketahui bahwa luas lahan ikut serta dalam menentukan hasil produksi petani padi di Desa makarti Kecamatan Kao Barat Kabupaten Halmehera Utara. keterangan tersebut menunjukan keikut serta luas lahan dalam menetukan hasil produksi petani padi di Desa makarti Kecamatan Kao Barat Kabupaten Halmahera sangat begitu besar karna rata-rata para petani hanya memliki luas lahan yang berukuran 0,75 ha karna hal tersebut di sebabkan petani hanya sebagai pindahan atau transmigrasi, jadi lahan yang di dapat juga hanya di berikan oleh pemerintah kabuapaten Halmahera utara.

Hal tersebut di perkuat dengan penelitian yang di lakukan oleh ahmat muyudin terhadap petani padi di Kecamatan Pekalongan Selatan tahun 2010, itu di karenakan luas lahan petani di sana berukuran sedang-sedang saja $0,50 \mathrm{Ha}$ (1/3ha) dan tidak mampu membeli tanah lagi untuk menambah hasil produksinya karna harganya yang sangat mahal. Selain itu sesuai dengan pendapat yang di nyatakan bahwa semakin luas lahan (yang di garap/ditanami), semaking besar jumlah produksi yang di hasilkan oleh lahan tersebut. (Abd. Rahim 2007). Hal ini juga berarti semaking sempit lahan yang di garap atau di Tanami semaking kecil pula jumlah produksi yang di hasilkan lahan tersebut.

\section{Modal}

Dari hasil penelitian untuk modal dalam menentukan hasil produksi dapat di sajikan pada Tabel 9.

Tabel 9. Penentu Modal Terhadap Hasil Produksi di Desa Makarti Kecamtan Kao Barat Kabupaten Halmahera Utara

\begin{tabular}{lcc}
\hline No. & Modal $(\mathrm{Rp})$ & Produksi (Karung) \\
\hline 1. & $3,452,500$ & 59 \\
2. & $4,588,500$ & 79 \\
3. & $6,007,500$ & 94 \\
4. & $7,985,000$ & 121 \\
\hline Rata-rata & $4,627,643$ & 77 \\
\hline
\end{tabular}

Berdasarkan Tabel 9 dapat di ketahui bahwa modal ikut menentukan hasil produksi petani padi. Dengan demikian Hal ini menunjukan bahwa modal sangat kecil 
menetukan produksi petani padi di Desa Makarti Kecamatan Kao Barat Kabupaten Halmahera Utara. Fakta tersebut di karnakan dengan modal yang di keluarkan hanya cukup untruk membeli bahan-bahan produksi dan membayar tenaga kerja sehingga tingkatan teknologi yang di gunakan sangat rendah sehingga hasil produksinyapun ikut rendah.

Ini sesuai dengan pendapat Moehar Daniel yang menyatakan bahwa modal adalah faktor terpenting dalam pertanian khususnya terkait bahan produksi dan biaya tenaga kerja. dengan kata lain modal sangat menentukan timgkat atau macam teknologi yang din terapkan. Kekurangan modal bias menyebabkan kurang masukan yang di berikan kepada proses pertanian sehingga menimbulkan resiko kegagalan atau rendahnya hasil yang akan di terima (Daniel, 2004).

\section{Tenaga Kerja}

Dari hasil penelitian untuk modal dalam menentukan hasil produksi dapat di sajikan pada Tabel 10.

Tabel 10. Penentu Tenaga Kerja Terhadap Hasil Produksi di Desa Makarti Kecamtan Kao Barat Kabupaten Halmahera Utara

\begin{tabular}{lcc}
\hline No. & $\begin{array}{c}\text { Tenaga Kerja } \\
(\text { HOK })\end{array}$ & Produksi (karung) \\
\hline 1. & $20-29$ & 61 \\
2. & $30-40$ & 74 \\
3. & $52-54$ & 118 \\
4. & $66-72$ & 125 \\
\hline Rata-Rata & 33 & 77 \\
\hline
\end{tabular}

Berdasarkan hasil penelitian menunjukan bahwa Untuk tenaga kerja menentukan secara positif terhadap produksi petani padi. Produksi petani padi di Desa Makarti Kecamatan Kao Barat Kabupaten Halmahera Utara sangat besar karna kebanyakan petani di sana menggunakan tambahan tenaga kerja hampir di setiap tahap pertanian mulai dari pengolahan tanah sampai pemanenan. Dimana jika menggunakan tenaga kerja tambahan di luar tenaga si pemilik, maka setiap tahapan pertanian tersebut akan mendapatkan hasil yang lebih optimal yang akhirnya berpengeruh dalam peningkatan hasil produksi pertanian.

Berdasarkan keterangan di atas sesuai dengan pernyataan yang menyatakan bahwa yang di maksud tenaga kerja adalah suatu alat kekuatan fisik dan otak manusia, yang tidak dapat di pisahkan dari manusia dan di tujukan pada usaha produksi setiap usaha pertanian nyang di usahakan pasti memerlukan tenaga kerja. Oleh karna itu dalam analisis ketenaga kerjaan di bidang pertanian menggunakan tenaga kerja di nyatakan oleh besarnya curahan tenaga kerja yang di pakai. Skala usaha akan menentukan besar kecilnya berapa tenaga kerja yang di butuhkan dan pula menentukan macam tenaga kerja yang bagaimana di perluhkan (Soekartawi, 1993).

Hasil penelitian menunjukan bahwa ketiga faktor yaitu luas lahan, modal, dan tenaga kerja yang di gunakan petani padi di Desa Makarti Kecamatan Kao Barat Kabupaten Halmahera Utara. Ternyata hanya sebagian kecil yang menghasilkan produksi yang tinggi. Hal tersebut memperkuat pendapat Soekartawi yang menyatakan untuk menghasilkan produksi (ouput) yang optimal maka penggunaan factor produksi dapat di gabungkan. Dalam pratek faktor-faktor produksi yang mempengaruhi produksi ini di bedahkan atas dua kelompok (Soekartawi, 1991).

a. Faktor biologis, seperti lahan pertanian dengan macam dan tingkat kesuburan, bibit, variates, pupuk, obat-obatan, gulma dan lain sebagainya.

b. Faktor sosial ekonomi, seperti biaya produksi, harga tenaga kerja, tingkat pendidikan, tingkat pendapatan, resiko dan ketidakpastian kelemabagaan, ketersedian kredit dan sebagainya.

Jadi dapat di simpulkan bahwa rerndahnya produksi padi petani di Desa Makarti Kecamatan Kao Barat Kabupaten Halmahera Utara selain di sebabkan oleh rendahnya faktor-faktor produksi tetapi juga oleh faktor biologis dan faktor sosial ekonomi. Faktor tersebut seperti bencana 
banjir, serangan hama tikus, serangan hama keong emas dan lain-lain.

Dari ketiga faktor yang di kaji, yang menentukan paling dominan terhadap produksi padi petani di Desa Makarti Kecamatan Kao Barat Kabupaten Halmahera Utara adalah factor tenaga kerja, penentu terbesar kedua adalah modal sebesar sedangkan yang menentukan paling kecil terhadap produksi padi petani di Desa Makarti Kecamatan Kao Barat Kabupaten Halmahera Utara adalah faktor luas lahan.

Berdasarkan hasil penelitian menunjukan bahwa secara bersama-sama luas lahan, modal, dan tenaga kerja menentukan hasil produksi padi petani di Desa Makarti Kecamatan Kao Barat Kabupaten Halmahera Utara.

Penentu antara luas lahan, modal dan tenaga kerja terhadap hasil produksi petani di Desa Makarti Kecamatan Kao Barat Kabupaten Halmahera Utara adalah penentu positif dan baik, di dalam produksi pertanian, faktor produksi memang menetukan besar kecilnya produksi yang akan di peroleh. Untuk menghasilkan produksi (ouput) yang optimal maka penggunaan faktor produksi tersebut dapat di gabungkan.

Dengan demikian dapat di jelaskan bahwa luas lahan, modal, dan tenaga kerja di tingkatkan maka akan di ikuti dengan meningkatkan produksi padi di Desa Makrti Kecamatan Kao Barat Kabupaten Halmahera Utara. Sebaliknya, jika luas lahan, modal dan tenaga kerja menurun maka akan di ikuti dengan menurunnya produksi padi di Desa Makarti Kecamatan Kao Barat Kabupaten Halmahera Utara.

\section{KESIMPULAN DAN SARAN}

\section{Kesimpulan}

Luas lahan menentukan secara baik terhadap hasil produksi, karna dengan di tambahkan luas lahan maka hasil produksi meningkat. Modal menentukan hasil produksi, karna dengan modal yang cukup maka para petani dapat melengkapi sarana produksi yang di butuhkan untuk meningkatkan hasil produksi. Tenaga Kerja ikut menentukan secara nyata terhadap produksi padi sawah petani di Desa Makarti Kecamatan Kao Barat Kabupaten Halmahera Utara, karena dari ketiga faktor tersebut sangat berkaitan erat dan saling mendukung dalam proses budidaya tanaman khususnya padi sawah.

\section{Saran}

Berdasarkan kesimpulan tersebut beberapa saran sebagai berikut:

Untuk meningkatkan hasil produksi padi sawah, maka petani padi di Desa Makarti Kecamatan Kao Barat Kabupaten Halmahera Utara perlu adanya penambahan luas lahan, modal, dan tenaga kerja, serta memanfaatkan sarana dan prasarana pertanian yang lebih efektif dan efisien dengan menerapkan paket teknologi sesuai anjuran mulai dari pemilihan benih, pemupukan, panen dan pasca panen.

Dalam proses ini juga perlu adanya memperhatikan aspek produktivitas lahan tersebut (jenis tanah, penggunaan tanah, pengairan dan sarana prasarana). Modal juga merupakan faktor yang sangat berpengaruh dalam menerapkan teknologi tepat guna.

\section{DAFTAR PUSTAKA}

Mosher Daniel. 2004. Pengantar Ekonomi Pertanian. Jakarta : PT. Bumi Aksara.

Rahim Abdul dan Diah Retno Dwi Hastuti. 2007. Ekonomika Pertanian (Pengantar, teori dan kasus). Jakarta :Penebar Swadaya.

Soekartawi, A. Soeharjo, J.L Dillon \& J.B Hardaker. 1984. Ilmu Usaha Tani \& Penelitian Untuk Pengembangan Petani Kecil. Jakarta: UI-Press.

1991. Agribisnis Teori dan Aplikasinya. Jakarta Rajawali Pers. 
Umar, Husein. 1998. Metode Penelitian untuk Skripsi dan Tesis. Jakarta: PT. Raja Grafindo Persada.

Wiratha I. Made. 2006. Metodologi Penelitian Sosial Ekonomi Yogyakarta: CV. Andi Offset. 